\title{
Incised valley filling deposits: an important pathway system for long-distance hydrocarbon migration-a case study of the Fulaerji Oilfield in the Songliao Basin
}

\author{
Xin Renchen ${ }^{1 *}$, Liu Hao ${ }^{1}$ and Li Guifan ${ }^{2}$ \\ ${ }^{1}$ School of Ocean Sciences, China University of Geosciences, Beijing 100083, China \\ ${ }^{2}$ School of the Earth Sciences and Resources, China University of Geosciences, Beijing 100083, China
}

\begin{abstract}
In this paper, incised valley filling deposits, which formed an important pathway system for long-distance hydrocarbon migration, are discussed in detail based on core and logging data. The sequence $\mathrm{SQ}_{y 23}$ of the Cretaceous Yaojia Formation is the main hydrocarbon-bearing layer in the Fulaerji Oilfield. The hydrocarbon source of the oilfield is the Qijia-Gulong Sag which is about $80 \mathrm{~km}$ away from the Fulaerji Oilfield. The transport layer of long-distance hydrocarbon migration is the overlapped sandstone complex which fills the incised valley. The incised valley developed during the depositional period from the late Qingshankou Formation to the early Yaojia Formation of Cretaceous $\left(\mathrm{SQ}_{\mathrm{qn}}-\mathrm{SQ}_{\mathrm{y} 1}\right)$ was about $70 \mathrm{~km}$ long and $20 \mathrm{~km}$ wide, and extended in the NW-SE direction. The overlapped filling of the incised valley mainly occurred in the expanding system tract of the third-order sequence $\mathrm{SQ}_{\mathrm{y} 23}\left(\mathrm{EST}_{\mathrm{y} 23}\right)$. Towards the basin, incised valley filling deposits overlapped on the delta developed in the early period, and towards the basin margin, incised valley filling deposits were covered by the shore-shallow lacustrine sandy beach bar developed in the maximum flooding period. All of the delta, the incised valley filling and the shore-shallow sandy beach bar are sandstone-rich, and have high porosity and permeability, and can form an effective hydrocarbon migration and accumulation system. Deltaic sand bodies collected and pumped hydrocarbon from the active source, incised valley filling depositional system completed the long-distance hydrocarbon migration, and lithological traps of shore-shallow lacustrine sandy beach bar accumulated hydrocarbon. The incised valley filling sequences are multi-cycle: an integrated shortterm filling cycle was developed on the erosion surface, and the sequences upward were mud-gravel stone, medium-fine sandstone containing terrigenous gravels and muddy pebbles with cross bedding, silty mudstone with ripple bedding, and mudstone. The incised valley filling deposits are characterized by a strong heterogeneity and the main hydrocarbon migration pathway is the medium-fine sandstone interval.
\end{abstract}

Key words: Songliao Basin, Fulaerji Oilfield, Yaojia Formation, incised valley filling, migration pathway system

\section{Introduction}

Migration pathway systems are an important link between source rocks and traps, and they are generally composed of faults, unconformities, and permeable skeleton sandbodies (Ghisetti and Vezzani, 2000; Nie et al, 2001; Chen and Kinzelbach, 2002; Hao et al, 2000). Previous research including litho-geochemistry (Lynch, 1996; Chowdhury and Noble, 1996), isotope geochemistry (Worden et al, 1999), fluid inclusion analysis (Kelly et al, 2000), and basin modeling methods (Hindle, 1997; Welte et al, 2001) focused on the main migration pathways of basin fluids, especially those of hydrocarbon. However, as an important

*Corresponding author. email: xinrenchen@163.com Received October 24, 2008 pathway system for long-distance hydrocarbon migration, incised valley filling deposits have not yet received adequate attention.

As sea level fell, fluvial depositional systems spread towards the basin and eroded the underlying strata, thus formed incised valleys (Van Wagoner et al, 1990; Ghinassi, 2007; Wescott, 1997). A great deal of research has been carried out on the formation and filling of incised valleys, which were controlled by relative change of sea level. Incised valleys formed during the early-middle period of sea level falling, and were gradually filled when sea level rose (Ferguson and Davis, 2003; Paola et al, 1992; Zaitlin et al, 1994; Allen and Posamentier, 1993; Zhang and Li, 1995; Li and Zhang, 1996). Research about incised valleys controlling hydrocarbon accumulation mainly focused on the control of lowstand lithologic traps (Sui et al, 2005; Xian et al, 2001; 
Huang et al, 2007). Whether traps without an effective hydrocarbon source can form oil and gas fields depends on the existence of a migration pathway system that links the effective hydrocarbon source and the traps, and incised valley filling deposits are a most important migration pathway system. The Fulaerji Oilfield of Songliao Basin is a typical reservoir formed by long-distance hydrocarbon migration through an incised valley filling deposit.

The Fulaerji Oilfield is located in the northern overlapping belt of the western slope area of the Songliao Basin. It is large in scale and its petroleum reserve is $1,575 \times 10^{7} \mathrm{~kg}$. The structural map of the top surface of the oil-bearing intervals indicates a slope inclining from west to east with a structural angle of $1.192^{\circ}$, and the structural lines are parallel with one another in the south-north direction. Faults are not developed in the oilfield and subtle nose-structures are developed in local areas. Effective hydrocarbon sources are scarce in the western slope area. The Qijia-Gulong Sag provided hydrocarbon for the Fulaerji Oilfield and the migration distance is longer than $80 \mathrm{~km}$ (Fig. 1).

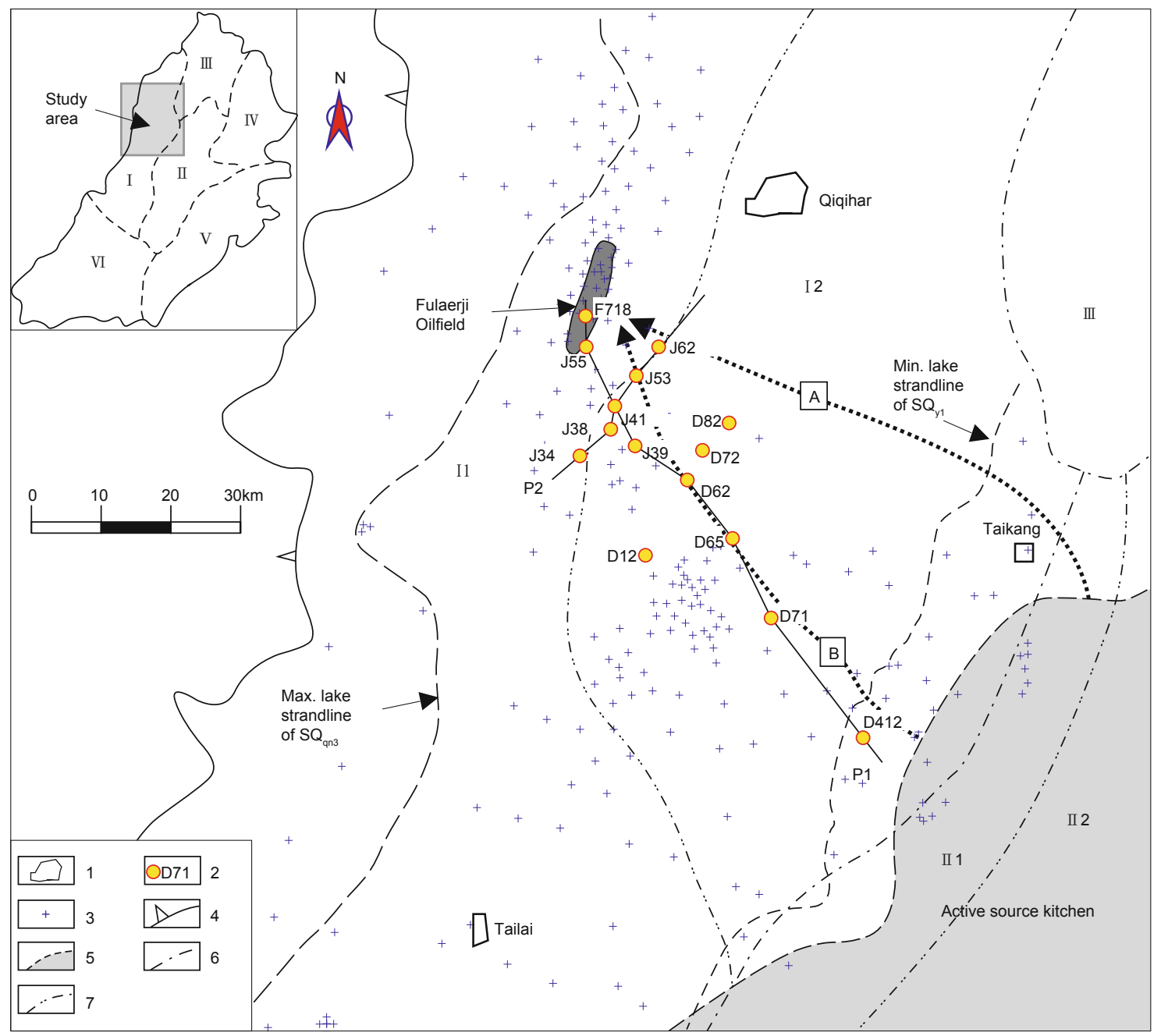

Fig. 1 Tectonic setting of the study area and distribution of the Fulaerji Oilfield and effective hydrocarbon sources I: Western Clinoform; I1: Tailai Overlap Zone; I2: Taikang Mole-track; II : Central Depression; II 1: Longhupao Terrace; II 2: Qijia Sag; III: Northern Clinoform; IV : Northeastern Uplift; V: Southeastern Uplift; VI: Southwestern Uplift; 1: city or town; 2: well mentioned in the paper; 3: well site; 4: boundary of the basin; 5 : Ro $\geq 0.7 \%$, active source kitchen; 6 : borderlines of secondorder structural unit; 7: borderlines of third-order structural unit; A: migration pathway recognized by Fu et al (2007); B: migration pathway recognized by Xiang et al (2004)

Much attention has been paid to the pathway system for long-distance hydrocarbon migration of the Fulaerji Oilfield for a long time. Xiang et al (2004) and Fu et al (2007) both proposed that structural ridges were the hydrocarbon migration pathway system of the Fulaerji Oilfield, but the locations of the migration pathways determined by them were different (Fig. 1). Based on detailed analysis of over 300 drilling wells by using sedimentology and petroleum geology methods, it is concluded that incised valley filling deposits are the hydrocarbon migration pathway of the Fulaerji Oilfield, and the sedimentary facies linkage and architecture of the incised valley pathway system were also discussed in depth. 


\section{Formation and filling of the incised valley in the north of western slope}

A great deal of research indicates that during the deposition of the Qingshankou and Nenjiang Formations, large-scale transgression occurred twice in the Songliao Basin (Gao and Xiao, 1995; Ye and Wei, 1996; Wei et al, 1996; Gao and Cai, 1997), which made the Songliao Basin develop into a deep-water depressional lacustrine basin. During this period, the lake was characterized by two periods of rising level and one of falling level and the lake area changed greatly. In the early depositional period of the Qingshankou Formation, the lake area was about $90,000 \mathrm{~km}^{2}$. During the late depositional period of the Qingshankou Formation and the early depositional period of the Yaojia Formation, local tectonism uplifted the Songliao Basin and the global sea level fell greatly in the upper Cretaceous (Haq et al, 1987), which led to a large-scale lowering of the lake level in the Songliao Basin and a decrease in the lake area, as shown in Fig. 2 (Gao and Cai, 1997; Xin et al, 2004; Xin and Wang, 2004). In the depositional period of Member 1 of Yaojia Formation, the smallest lake area was less than $10,000 \mathrm{~km}^{2}$ (Gao and Cai, 1997), and the second-order sequence boundary between the Cretaceous $\mathrm{SSQ}_{\mathrm{q}-\mathrm{qn}}$ and $\mathrm{SSQ}_{\mathrm{y}-\mathrm{n}}$ was formed. This sequence boundary showed obvious characteristics in seismic, logging, lithologic and paleontological data (Gao and Xiao, 1995; Wei et al, 1996; Gao and Cai, 1997; Xin et al, 2004; Gao et al, 1994; Ye et al, 2002; Liu et al, 2002; Wei, 1996; Wang et al, 2005). During the depositional period of Members 2 and 3 of Yaojia Formation, the lacustrine basin expanded again. In the early depositional period of the Nenjiang Formation, the lake level of the basin reached its second peak and the lake area was over $120,000 \mathrm{~km}^{2}$.

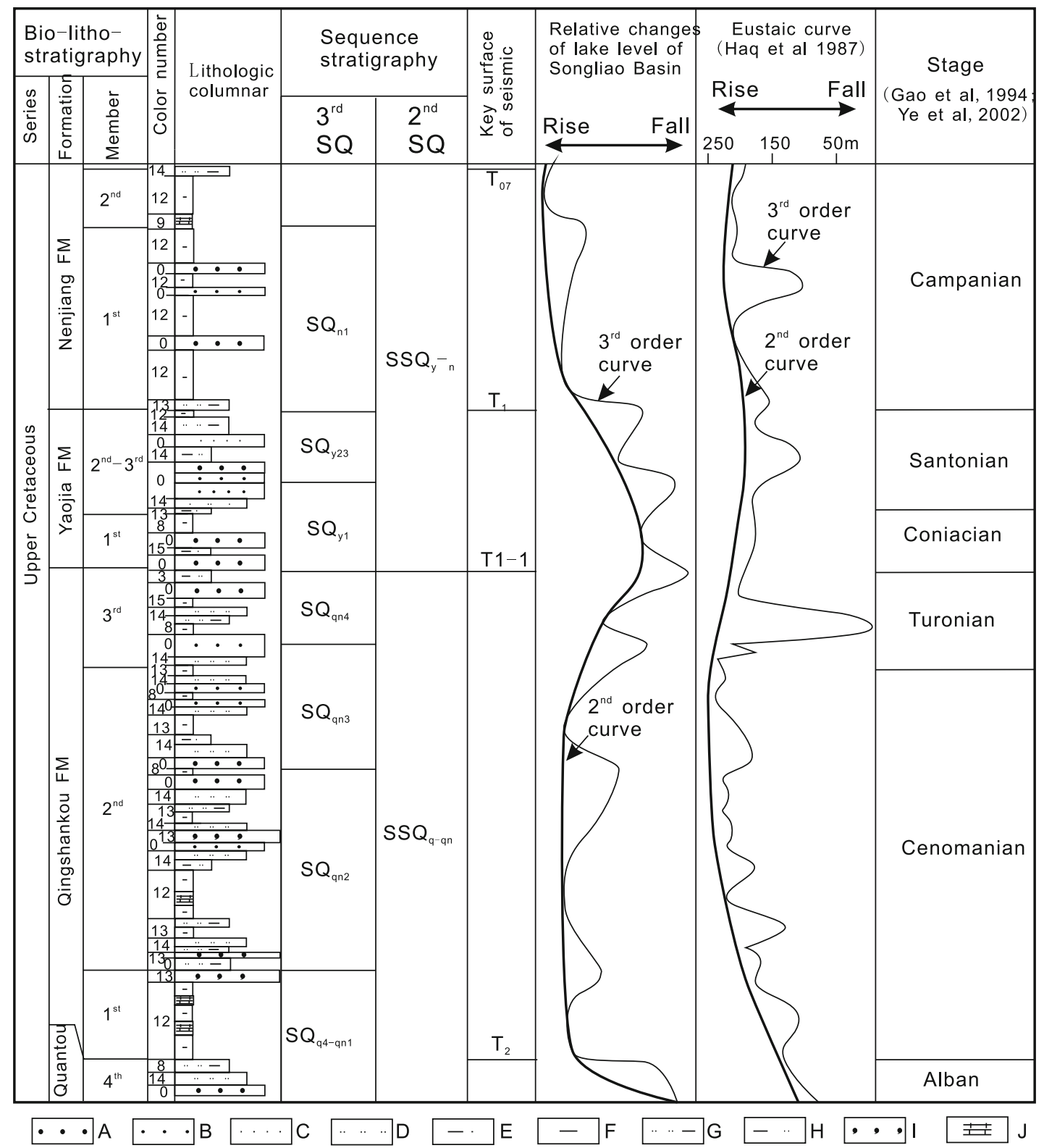

Fig. 2 The sequence stratigraphic framework from the Qingshankou Formation to the Member 1 of Nenjiang Formation of the central Songliao Basin A: coarse sandstone; B: medium sandstone; C: fine sandstone; D: siltstone; E: muddy sandstone; F: mudstone; G: muddy siltstone; H: silt mudstone; I: Ostracoda layer; J: oil shale; 0: light grey; 8: dark green; 12: black; 13: dark grey; 14: grey; 15: dark purple 
From Member 1 of Qingshankou Formation to Member 1 of Nenjiang Formation, the strata were divided into seven third-order sequences and two second-order sequences according to detailed analysis of paleontological, lithologic, logging and seismic data. Sequences $\mathrm{SQ}_{\mathrm{q} 4-\mathrm{qn} 1}, \mathrm{SQ}_{\mathrm{qn} 2}, \mathrm{SQ}_{\mathrm{qn} 3}$, and $\mathrm{SQ}_{\mathrm{qn} 4}$ belonged to the second-order sequence $\mathrm{SSQ}_{\mathrm{q}-\mathrm{qn}}$, and $\mathrm{SQ}_{\mathrm{y} 1}, \mathrm{SQ}_{\mathrm{y} 23}$, and $\mathrm{SQ}_{\mathrm{n} 1}$ belonged to the second-order sequence $\mathrm{SSQ}_{\mathrm{y}-\mathrm{n}}$ (Fig. 2).

During the depositional period from late Qingshankou Formation to early Yaojia Formation, the lake shrank and the shoreline of the western slope area shifted towards the central sag area on a large scale (Fig. 1). Most of the western slope area was exposed, which led to cessation of deposition. Compared with the complete stratigraphic sequences of the Songliao Basin (Fig. 2), the third-order sequences $\mathrm{SQ}_{\mathrm{qn} 4}$ and $\mathrm{SQ}_{\mathrm{y} 1}$ were not developed in most of the western slope area (Fig. 5).

During the depositional period from the Qingshankou Formation to the Yaojia Formation, the Qiqihar stream system was well developed in the western slope of the Songliao Basin (Gao and Cai, 1997). During the depositional period from late Qingshankou Formation to early Yaojia Formation (from $\mathrm{SQ}_{\mathrm{qn} 4}$ to $\mathrm{SQ}_{\mathrm{y} 1}$ ), an incised valley was formed in the western slope area due to the influence of the Qiqihar stream system. Its length was $70 \mathrm{~km}$ and width was $20 \mathrm{~km}$, and extended in the NW-SE direction. The filling of the incised valley mainly occurred in the expanding system tract of the third-order sequence $\mathrm{SQ}_{\mathrm{y} 23}$.

\section{Linkage of the depositional system related to incised valley filling}

The complete depositional system linkage related to incised valley filling is delta-incised valley fillingshoreline sandy beach bar.

The incised valley was gradually filled during the rising of lake (sea) level. In the lower lake (sea) level period, the incised valley, as the transport passage for sands, transported a great deal of clasts to the deep-water area, which led to the development of sublacustrine fan or delta deposits, later it was mainly dominated by delta deposits. During the period of rising lake levels, the incised valley was gradually drowned, and a lot of riverine sediments deposited. The incised valley was gradually filled due to river-lake (sea) interaction in the incised valley. In the maximum lake (sea) level stage, the shoreline reached the top of the incised valley in the adjacent provenance area. The clasts from the provenance area were mainly influenced by lake (sea) waves and formed shore-shallow lacustrine (marine) sandy beach bar deposits near the shoreline. The linkages of the incised valley filling depositional system are as follows: towards the central basin, the incised valley filling deposit is connected with the delta developed in the early period, and towards the basin margin, the incised valley filling deposit is connected with the shore-shallow lacustrine sandy beach bar developed in the maximum flooding period.

The Cretaceous incised valley filling in the north of the western slope of the Songliao Basin mainly occurred during the expanding system tract of the third-order sequence $\mathrm{SQ}_{\mathrm{y} 23}$.
The planar distribution map of the expanding system tract of sequence $\mathrm{SQ}_{\mathrm{y} 23}$ was compiled based on the data of over 300 drilling wells, which indicated the spatial distribution of the incised valley filling depositional system (Fig. 3).

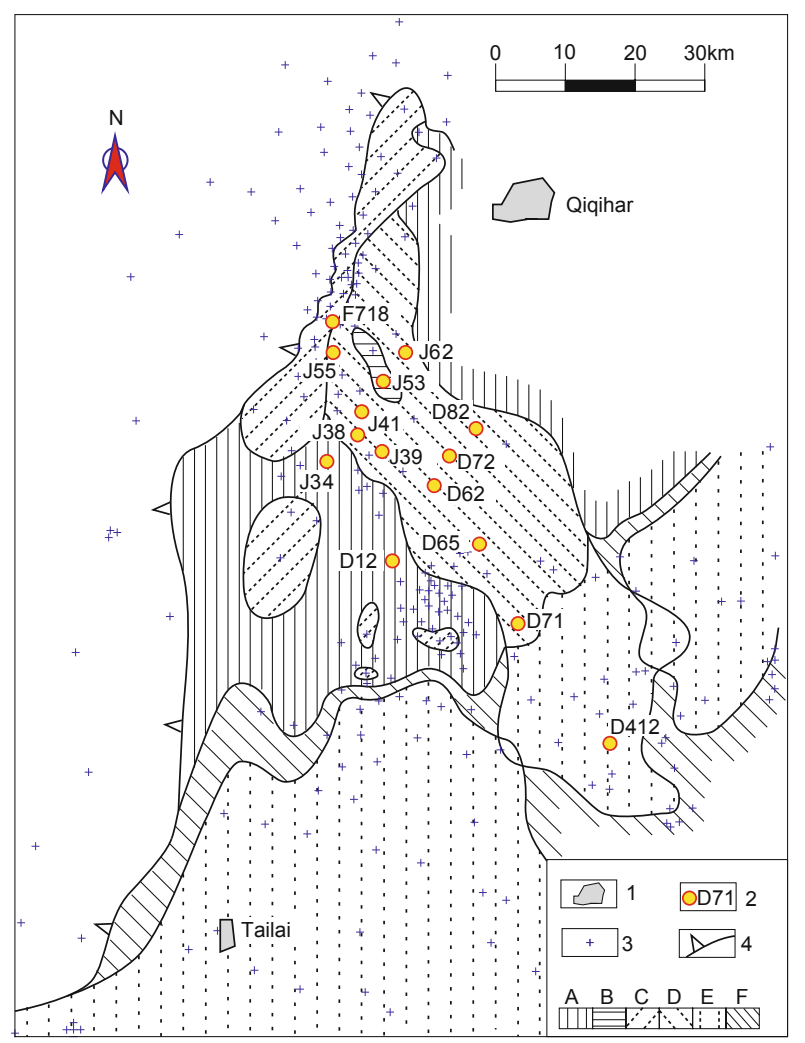

Fig. 3 Depositional system of $\mathrm{EST}_{\mathrm{y} 23}$ in the north of the western slope of the Songliao Basin

1: city or town; 2: key well; 3: drilling well; 4: pinchout line; A: mud and sand mixture beach of shore-shallow lacustrine; B: relic erosion highland; C: sand beach of shore-shallow lacustrine; D: incised valley filling; E: mouth bar of delta front; F: distal bar of delta front

During the early period of expanding system tract of $\mathrm{SQ}_{\mathrm{y} 23}\left(\mathrm{EST}_{\mathrm{y} 23}\right)$, the incised valley, as a passage for sand transportation, carried large quantities of clasts to the deep lake basin area southeast of Well D71 and formed a sand-rich delta depositional system along the area from Well D71 to Well D412. In the rising lake level stage of $\mathrm{SQ}_{\mathrm{y} 23}$, the incised valley was gradually drowned by lake water. The river carrying clasts was influenced by lake water, and the clasts deposited and filled the incised valley in the river-lake interaction area. The incised valley filling deposit with length of $70 \mathrm{~km}$ and width of $20 \mathrm{~km}$ was formed along the area from Well J55 to D71. In the incised valley filling system, a relic erosion highland was developed near Well J53 whose sediments were mainly mudstones depositing from suspended load. When the lake level rose to the maximum, the shoreline reached the top of the incised valley in the adjacent provenance area. Clasts coming from the provenance area were mainly controlled by the lake waves and formed sand-rich sandy beach bar deposits in shore-shallow lacustrine areas.

The delta depositional system, incised valley filling depositional system, and shore sandy beach bar in the depositional system linkage related to incised valley filling 
are all characterized by the development of sandstones and a high sand content, generally over $40 \%$ (Fig. 4). The sand content of sandy shore beach bar is usually over $60 \%$ and in local areas over $80 \%$. Sandstone layers with sand content higher than $60 \%$ which means relatively high porosity and permeability are favorable for hydrocarbon migration and accumulation.

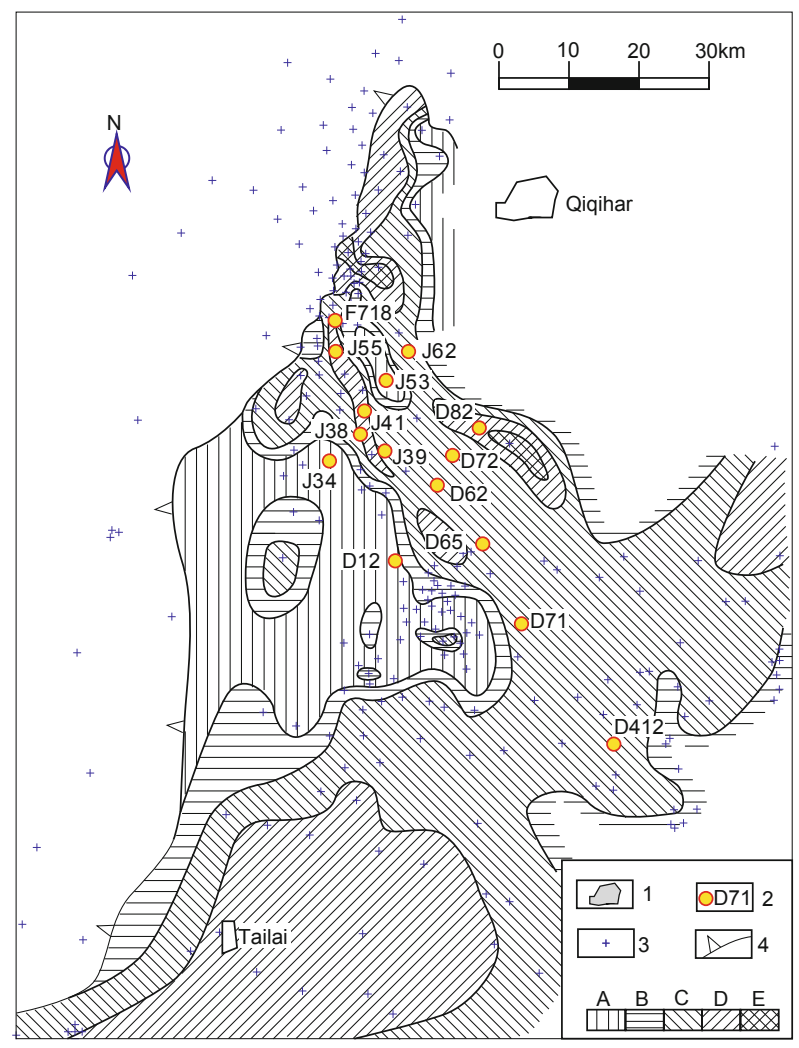

Fig. 4 Sandstone percentage of $\mathrm{EST}_{\mathrm{y} 23}$ in the north of the western slope of the Songliao Basin

1: city or town; 2: key well; 3: drilling well; 4: pinchout line percentage of sandstones A: $0 \%-20 \%$; B: $20 \%-40 \%$; C: $40 \%-60 \%$; D: $60 \%-80 \%$; E: $80 \%-100 \%$

\section{Architecture of the incised valley filling depositional system and hydrocarbon migration and accumulation}

The incised valley filling depositional system is characterized by its multi-cycle architecture. In the dip profile of incised valley, tracing the source from the slope break, sand bodies overlap layer by layer along the bottom surface of the incised valley, and split and pinch out into mudstones towards the basin. The sandstones, which overlap along the bottom surface of incised valley whose slope gradient is a little more than $8.5 \mathrm{~m} / \mathrm{km}$ nowadays, are transport layers for hydrocarbon migration and accumulation.

Fig. 5 is the cross section in the dip direction of the incised valley (the location of the section is shown as P1 in Fig. 1) and in the strike direction of the incised valley (the location of the section is shown as P2 in Fig. 1).

Obvious slope breaks appeared in the area between Well
D412 and Well D71 in the dip direction profile. Sequences of Well D412 below the slope break are complete, while sequences $\mathrm{SQ}_{\mathrm{qn} 4}$ and $\mathrm{SQ}_{\mathrm{y} 1}$ are not developed above the slope break. Erosion and incision occurred above the slope break during the deposition of sequences $\mathrm{SQ}_{\mathrm{qn} 4}$ and $\mathrm{SQ}_{\mathrm{y} 1}$, and the incised valley was formed. Incised valley filling occurred during the expanding system tract of sequence $\mathrm{SQ}_{\mathrm{y} 23}$ and formed incised valley filling deposits which could be divided into five short-term cycles (A, B, C, D, and E in Fig. 5).

The incised valley filling sand bodies formed during the initial short-term cycle (A in Fig. 5) were developed along the area from Well D71 to D412, and had an erosion contact with the underlying delta sand bodies of highstand system tract of sequence $\mathrm{SQ}_{\mathrm{y} 1}$. Sand bodies adjacent to the Well D71 slope break had the largest thickness, and overlapped and pinched out in the up-dip direction to the east of Well D65, while gradually thinning towards the basin. The sand bodies were covered by muddy intervals which thinned and pinched out towards the basin margin.

The incised valley filling sand bodies formed during the second short-term cycle (B in Fig. 5) were developed along the area from Well D65 to D412. The sand bodies were characterized by stable thickness and directly covered the sand bodies of the first short-term cycle to the west of Well D71. In the up-dip direction of slope, the sand bodies overlapped and pinched out to the east of Well D62 and were covered by muddy intervals which thinned and pinched out towards the basin margin.

The incised valley filling sand bodies formed during the third short-term cycle (C in Fig. 5) were developed on the slope along the area from Well D62 to D65 and in the deeply incised valley adjacent to Well J41. Sand bodies in the former area directly covered the sand bodies of the second shortterm cycle to the west of Well D65, overlapped and pinched out in the up-dip direction of the slope to the east of Well J39, and split and pinched out towards the basin. The sand bodies were covered by muddy intervals which thinned and pinched out towards the basin margin. The deeply incised valley sand bodies adjacent to Well J41 were sand lenses and directly contacted with the sand bodies of the short-term cycles in later periods.

The incised valley filling sand bodies formed during the fourth short-term cycle (D in Fig. 5) were developed along the area from Well J41 to D62. Sand bodies near the Well J39 had the largest thickness, and directly covered the sand bodies of the third short-term cycle to the west of Well D62. The sand bodies overlapped and pinched out in the up-dip direction of the slope to the east of Well J55, and thinned and pinched out towards the basin. The sand bodies were covered by muddy intervals which thinned and pinched out towards the basin margin.

The fifth short-term cycle was developed during the period of maximum lake level. Shore-shallow sandy beach bar sand bodies were formed near the maximum lake shoreline along the area from Well F718 to J55 (E in Fig. 5) and directly covered the sand bodies of the fourth short-term cycle to the west of Well J41. The sandstones were developed with stable thickness along the area from Well F718 to J55, quickly pinched out towards the basin, changed into lacustrine 


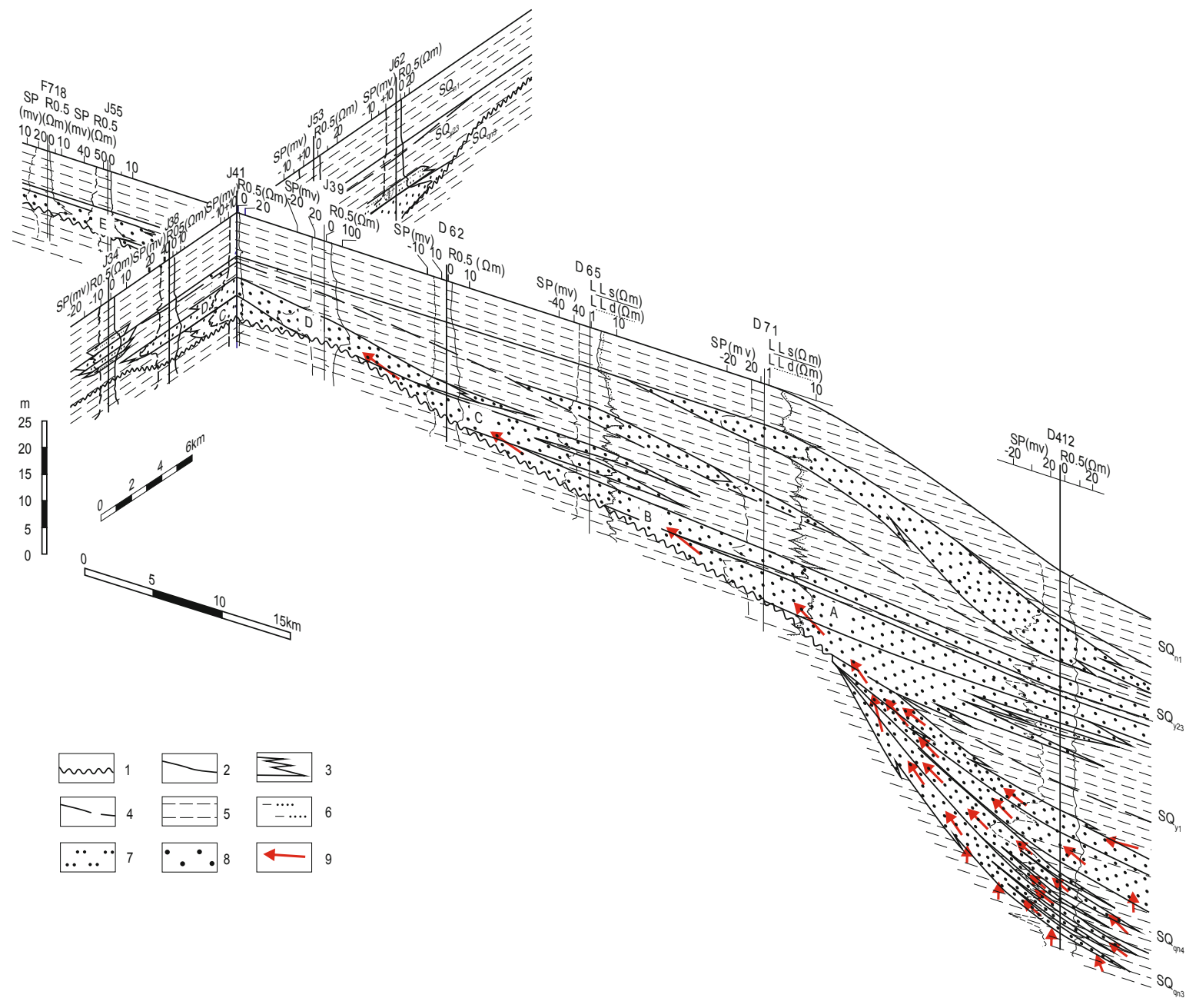

Fig. 5 Cross section in the dip direction and in the strike direction of incised valley (the position of the section is shown as P1 and P2 in Fig. 1)

$1: 2^{\text {nd }}$ sequence boundary; $2: 3^{\text {rd }}$ sequence boundary; $3:$ lithologic surface; 4 : maximum flooding surface of lake; $5:$ mudstone; 6: muddy siltstone; 7: siltstone; 8: medium-fine sandstone; 9: oil transport direction

mudstones, and were covered by mudstones.

In the strike profile, the sand bodies are present lens shaped with staggered overlap, the early sand bodies were developed at relatively lower levels in the valley, such as near the Well J41 and near the Well J62 in Fig. 6, while the higher levels in the valley are dominated by mudstones, such as near the Well J53 in Fig. 5, and the later sand bodies were not limited by the bottom of the valley. In the period of maximum lake level of $\mathrm{SQ}_{\mathrm{y} 23}$, the incised valley is filled mainly by muddy sediments (Fig. 5).

A complete hydrocarbon accumulation system was formed by the depositional system linkage related to incised valley filling as follows: deltaic sand bodies collected and pumped hydrocarbon from the active source, incised valley filling depositional system completed the long-distance hydrocarbon migration, and lithological traps of shore-shallow lacustrine sandy beach bar accumulated hydrocarbon. Besides, other traps in this hydrocarbon accumulation system can also form reservoirs. Oil and gas fields including Talahong Gasfield, Baiyinnuole Gasfield, Erzhan Gasfield, Alaxin Gasfield, and Jiangqiao Oilfield were discovered in the western slope of the
Songliao Basin. They are distributed in a "string of beads" shape and the hydrocarbon transport is probably also related to the accumulation system of the incised valley filling depositional system.

Incised valley filling depositional system is characterized by the multi-stage filling of sandstones and mudstones. The lower part of incised valley filling depositional system is dominated by sandstones and has lower content of mudstones, while there is a higher content of mudstones and lower content of sandstones in the upper part. Incised valley filling deposits have different hydrocarbon transport capability due to their different lithology which is shown as the obvious heterogeneity. Medium-fine sandstones with higher porosity and permeability are the main transport layers and constitute the dominant migration passages (Fig. 6).

The core data of Well D71 indicate two short-term filling cycles of the incised valley and the oil-bearing properties of different lithological intervals, which clearly reflect the main intervals for hydrocarbon transport (Fig. 6). The lower part is a complete short-term cycle with an erosion surface as its bottom boundary. Above the erosion surface, the 


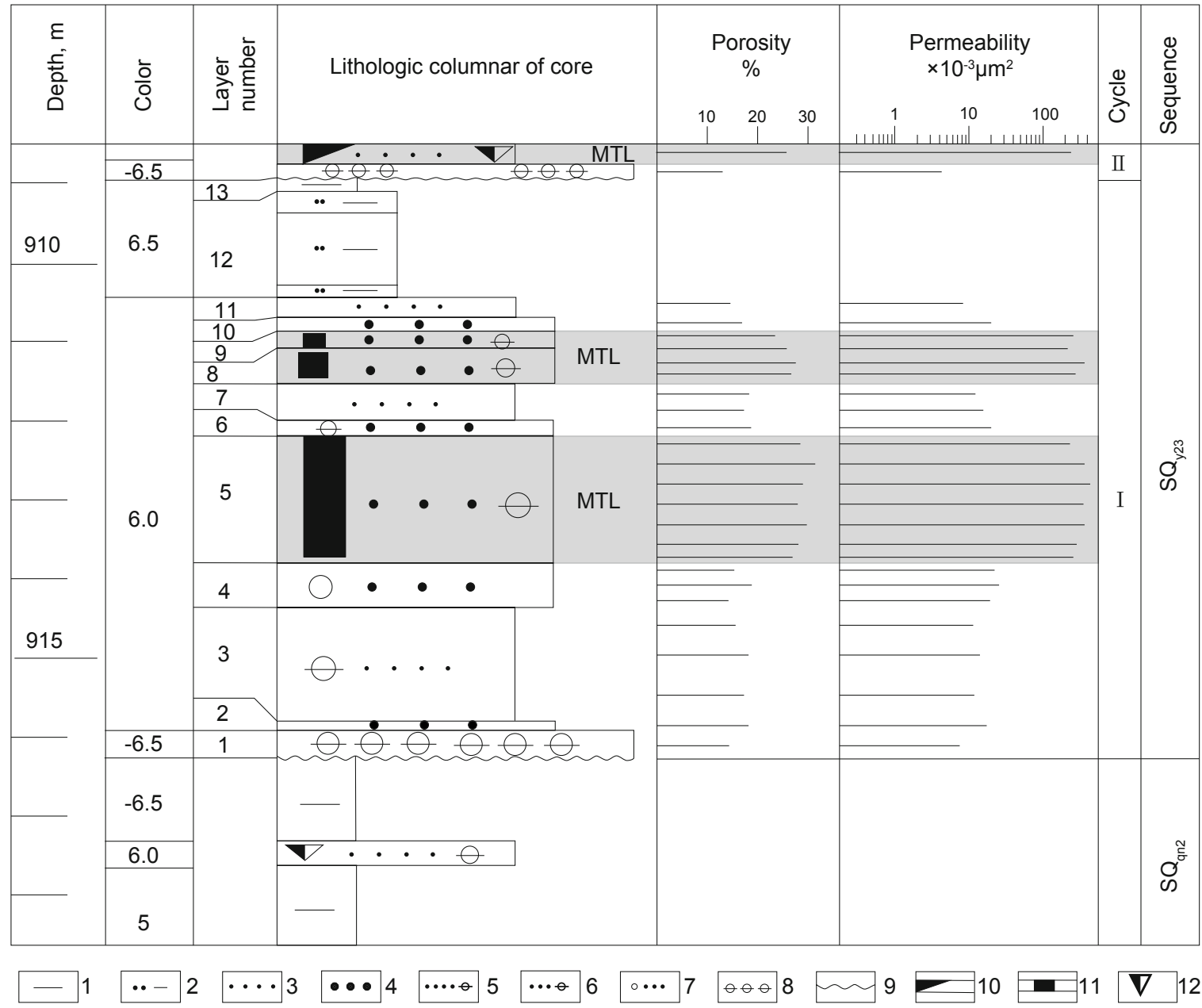

Fig. 6 Core data of the incised valley filling of Well D71 (the well location is shown in Fig. 1)

1: mudstones; 2: silty mudstones; 3: fine sandstones; 4: medium sandstones; 5: fine sandstones with muddy pebbles; 6: medium sandstones with muddy pebbles; 7: pebbly medium sandstones; 8: mud-gravel stone; 9: scour surface; 10: oil-rich layer; 11: oil-soaked layer; 12: oil spot layer; Color code: 0 white; 5 green; 6 grey; + dark color; - light color; MTL: main transport layer

depositional sequences are as follows: (1) $30 \mathrm{~cm}$ thick light gray green muddy conglomerates with no oil or gas shows; (2) $10 \mathrm{~cm}$ thick light gray white medium sandstones with no oil or gas shows; (3) $1.5 \mathrm{~m}$ thick gray white fine sandstones with development of wavy cross-bedding, muddy pebbles, calcareous nodule and with no oil or gas shows; (4) $30 \mathrm{~cm}$ thick gray white conglomerate-bearing medium sandstones with no oil or gas shows; (5) oil-soaked layer, $1.7 \mathrm{~m}$ thick gray white medium sandstones with development of lowangle cross-bedding and muddy pebbles; (6) $10 \mathrm{~cm}$ thick gray white medium sandstones with development of muddy pebbles and pyrite and with no oil or gas shows; (7) 25 $\mathrm{cm}$ thick gray white fine sandstones with development of wavy cross-bedding and low-angle cross-bedding and with no oil or gas shows; (8) oil-soaked layer, $25 \mathrm{~cm}$ thick gray white medium sandstones with development of wavy crossbedding, muddy pebbles, carbonaceous clasts, and pyrite; (9) oil-soaked layer, $10 \mathrm{~cm}$ thick gray white medium sandstones with development of wavy bedding, and carbonaceous clasts; (10) $10 \mathrm{~cm}$ thick gray white medium sandstones with thinlayer mudstones interbedded, wavy bedding and with no oil or gas shows; (11) $10 \mathrm{~cm}$ thick gray white fine sandstones with development of wavy cross-bedding with muddy bands and with no oil or gas shows; (12) $10 \mathrm{~cm}$ thick gray green silty mudstones with sandy bands, with development of wavy bedding and with no oil or gas shows; (13) 1 m thick gray green silty mudstones with no oil or gas shows.

The upper short-term filling cycle was an incomplete one, which indicated the erosion of the bottom part, and above the erosional surface, muddy conglomerates and petroliferous fine-grained sandstones with cross-bedding were respectively developed.

The results indicate that incised valley filling deposits are characterized by obvious heterogeneity. The medium sandstones of (5), (8), and (9) of the lower short-term cycle are the main transport layers for hydrocarbon migration. The thickness of the transport layers is about $2.05 \mathrm{~m}$, and that of the lower short-term cycle is a little more than $6 \mathrm{~m}$, so the transport layers account for about $33 \%$ of the lower shortterm cycle of incised valley filling.

\section{Conclusions}

1) The hydrocarbon of the Fulaerji Oilfield is derived from 
the Qijia-Gulong Sag (Feng et al, 2003) and the hydrocarbon migration distance is over $80 \mathrm{~km}$. This study clarified that incised valley filling deposits were the hydrocarbon transport layer systems, and the structural ridge passages for hydrocarbon migration proposed by Xiang et al (2004) were situated in the incised valley filling deposits.

2) Towards the basin, incised valley filling deposits joined with the delta formed in the early period, while towards the basin margin, they joined with the shore-shallow lacustrine beach bar sandbodies developed during the maximum lake level in the basin margin area. Consequently, a complete sedimentary system is formed, i.e., delta system-incised valley filling system - shore facies sandy beach bar system, which are all characterized by the development of sandstones with high sand content, high porosity, and high permeability. The porosity is about $26 \%-30 \%$ and the permeability is about $160 \times 10^{-3} \mu \mathrm{m}^{2}$ to $280 \times 10^{-3} \mu \mathrm{m}^{2}$, so these systems have good capability for hydrocarbon transportation and accumulation.

3) The incised valley filling depositional system is characterized by its multi-cycle architecture. In the dip profile of the incised valley, tracing the source from the slope break, sand bodies overlap layer by layer along the bottom surface of incised valley, and split and pinch out into mudstones towards the basin. The sandstones, which overlap along the bottom surface of incised valley, are transport layers for hydrocarbon migration and accumulation. A complete hydrocarbon accumulation system was formed by the depositional system linkage related to incised valley filling as follows: deltaic sand bodies collected and pumped hydrocarbon from the active source, incised valley filling depositional system completed the long-distance hydrocarbon migration, and lithological traps of shore-shallow lacustrine sandy beach bar accumulated hydrocarbon. Besides, other traps in this hydrocarbon accumulation system can also form reservoirs.

4) Incised valley filling deposits have different hydrocarbon transport capability due to their different lithology which is shown as the obvious heterogeneity. Medium-fine sandstones with higher porosity and permeability are the main transport layers and constitute the dominant migration passages. The actual transport layers account for about $33 \%$ of the lower short-term cycles of incised valley filling deposits based on the core data of Well D71. Dembicki and Anderson (1989), Thomas and Clouse (1995) and Xin et al (2002) carried out experiments about hydrocarbon migration and obtained similar conclusions, i.e., petroleum migration passages are very limited in potential hydrocarbon transport layers, and the actual migration passages come from only $10 \%$ of the potential transport layers.

\section{References}

Allen G P and Posamentier H W. Sequence stratigraphy and facies model of an incised valley fill: the Gironde Estuary, France. Journal of Sedimentary Research. 1993. 63(3): 378-391

Chen Q and Kinzelbach W. An NMR study of single- and two-phase flow in fault gouge filled fractures. Journal of Hydrology. 2002. 259(1-4): 236-245

Chowdhury A H and Noble J P A. Origin, distribution and signification of carbonate cements in the Albert Formation reservoir sandstones, New Brunswick, Canada. Marine and Petroleum Geology. 1996.

\section{3(7): 837-846}

Dembicki H and Anderson M J. Secondary migration of oil: experiments supporting efficient movement of separate, buoyant oil phase along limited conduits. AAPG Bulletin. 1989. 73(8): 1018-1021

Feng Z H, Liao G Z, Fang W, et al. Formation of heavy oil and correlation of oil-source in the western slope of the northern Songliao Basin. Petroleum Exploration and Development. 2003. 30(4): 25-28 (in Chinese)

Ferguson T W and Davis R A. Post-Miocene stratigraphy and depositional environments of valley-fill sequences at the mouth of Tampa Bay, Florida. Marine Geology. 2003. 200(1): 157-170

Fu X F, Wang P Y, Lü Y F, et al. Tectonic features and control of oil-gas accumulation in the west slope of Songliao Basin. Chinese Journal of Geology. 2007. 42(2): 209-222 (in Chinese)

Gao R Q and Cai X Y. The Formation Conditions and Distribution Rules of Oil and Gas Pools of Songliao Basin. Beijing: Petroleum Industry Press. 1997. 47-103 (in Chinese)

Gao R Q and Xiao D M. Advances in Oil and Gas Exploration in the Songliao Basin and Surrounding Basins. Beijing: Petroleum Industry Press. 1995. 19-24 (in Chinese)

Gao R Q, Zhang Y and Cui T C. Cretaceous Oil and Gas Strata of the Songliao Basin. Beijing: Petroleum Industry Press. 1994. 6-47 (in Chinese)

Ghinassi M. The effects of differential subsidence and coastal topography on high-order transgressive-regressive cycles: Pliocene nearshore deposits of the Val d'Orcia Basin, Northern Apennines, Italy. Sedimentary Geology. 2007. 202(4): 677-701

Ghisetti F and Vezzani L. Detachments and normal faulting in the Marche fold-and-thrust belt (central Apennines, Italy): inferences on fluid migration paths. Journal of Geodynamics. 2000. 29(3-5): $345-$ 369

Hao F, Zou H Y and Jiang J Q. Dynamics of petroleum accumulation and its advances. Earth Science Frontiers. 2000. 7(3): 11-21 (in Chinese)

Haq B U, Hardenbol J and Vail P R. Chronology of fluctuating sea-levels since the Triassic. Science. 1987. 235(4793): 1156-1167

Hindle A D. Petroleum migration pathways and charge concentration: a three-dimensional model. AAPG Bulletin. 1997. 81(9): 1451-1481

Huang C Y, Wang H, Xiao D Q, et al. Sequence patterns, characteristics of depositional systems and model of reservoirs of fault steep slope belt of the First Member of Shahejie Formation in Banqiao Sag. Acta Sedimentologica Sinica. 2007. 25(3): 386-391 (in Chinese)

Kelly J, Parnell J and Chen H H. Application of fluid inclusions to studies of fractured sandstone reservoirs. Journal of Geochemical Exploration. 2000. 69-70: 705-709

Li C X and Zhang G J. Progress on high resolution sequence stratigraphy in incised paleovalley. Advance in Earth Sciences. 1996. 11(2): 216219 (in Chinese)

Liu Z J, Dong Q S, Wang S M, et al. Introduction and Application of Continental Sequence Stratigraphy. Beijing: Petroleum Industry Press. 2002. 113-137 (in Chinese)

Lynch F L. Mineral/water interaction, fluid flow, and Frio sandstone diagenesis: evidence from the rocks. AAPG Bulletin. 1996. 80(4): 486-504

Nie F J, Li S T, Wang H, et al. Lateral migration pathways of petroleum in the Zhu III subbasin, Pearl River Mouth Basin, South China Sea. Marine and Petroleum Geology. 2001. 18(5): 561-575

Paola C, Hellert P L and Angevine C L. The large-scale dynamics of grain-size variation in alluvial basins. I: Theory. Basin Research. 1992. 4(2): 73-90

Sui F G, Guo Y X, Wang B Y, et al. Fault break-slope and low-stand fan sequence in Dongying Sag. Petroleum Exploration and Development. 2005. 32(2): 63-67 (in Chinese)

Thomas M M and Clouse J A. Scaled physical model of secondary oil migration. AAPG Bulletin. 1995. 79(1): 19-29 
Van Wagoner J C, Mitchum R M, Campion K M, et al. Siliciclastic sequence stratigraphy in well logs, cores and outcrops. AAPG Methods in Exploration. 1990. Series 7: 1-55

Wang Y, Wang Y M, Zhao Z K, et al. Origin and evolution of the west slope belt in Member 4 of Quantou Formation to Yaojia Formation, south Songliao Basin. Petroleum Exploration and Development. 2005. 32(3): 33-36 (in Chinese)

Wei K S. Nonmarine Basin Sequence Stratigraphy_A Case Study of the Songliao Basin. Beijing: Geological Publishing House. 1996. 46-94 (in Chinese)

Wei K S, Ye S F, Guo Z Q, et al. Sequence stratigraphic model of nonmarine sediments in Cretaceous, Songliao Basin. Acta Sedimentologica Sinica. 1996. 14(4): 50-60 (in Chinese)

Welte D H, Hantschel T, Wygrala B P, et al. Aspects of petroleum migration modelling. Journal of Geochemical Exploration. 2001. 6970: 711-714

Wescott W A. Channel and valley: Difference in word or meaning? The Leading Edge. 1997. 6: 867-873

Worden R H, Coleman M L and Matray J M. Basin scale evolution of formation waters: A diagenetic and formation water study of the Triassic Chaunoy Formation, Paris Basin. Geochimica et Cosmochimica Acta. 1999. 63(17): 2513-2528

Xian B Z, Jiang Z X, Cao Y C, et al. Discovery of incised valley in southeast of Biyang Depression and its significance. Oil \& Gas Geology. 2001. 22(4): 304-308 (in Chinese)

Xiang C F, Xia B, Xie X N, et al. Major hydrocarbon migration pathway system in western slope zone of Songliao Basin. Oil \& Gas Geology.
2004. 25(2): 204-208 (in Chinese)

Xin R C and Wang Y M. Origin and evolution of west slope breaks of Qingshankou-Yaojia Formation in northern Songliao Basin. Earth Science-Journal of China University of Geosciences. 2004. 29(5): 621-624 (in Chinese)

Xin R C, Cai X Y and Wang Y M. Depositional model of lowstand and characteristics of sequence boundary in deep-water lake, Songliao Depression Basin. Acta Sedimentologica Sinica. 2004. 22(3): 387392 (in Chinese)

Xin R C, Jiang Z X and Li S T. Physical modeling of secondary oil migration and accumulation in deltaic sandstone reservoir and its result analysis. Earth Science-Journal of China University of Geosciences. 2002. 27(6): 780-782 (in Chinese)

Ye D Q, Huang Q H, Zhang Y, et al. Cretaceous Biostratigraphy in the Songliao Basin. Beijing: Petroleum Industry Press. 2002. 53-98 (in Chinese)

Ye S F and Wei K S. Condensed section and new evidence of marine inundation in Cretaceous, Songliao Basin. Earth Science-Journal of China University of Geosciences. 1996. 21(3): 267-271 (in Chinese)

Zaitlin B A, Dalrymple R W and Boyd R. The stratigraphic organization of incised valley systems associated with relative sea-level changes. In: Incised Valley Systems: Origin and Sedimentary Sequence (edited by Dalrymple R W, Boyd R and Zaitlin B A). SEPM Special Publication. 1994. 51: 45-60

Zhang G J and Li C X. The infilling of the incised Qiantang River paleovalley and its sequence stratigraphic characteristics. Marine Geology \& Quaternary Geology. 1995. 15(4): 57-67 (in Chinese)

(Edited by Hao Jie) 